\title{
Pengaruh Pembelajaran Problem Based Learning dengan Pendekatan Metakognisi terhadap Kemampuan Pemecahan Masalah Matematis
}

\author{
Geni Sri Elita1 ${ }^{*}$, Mhmd Habibi' ${ }^{2}$, Aan Putra ${ }^{3}$, dan Nelpita Ulandari ${ }^{4}$ \\ 1*,2,3,4Program Studi Pendidikan Matematika, Institut Agama Islam Negeri Kerinci \\ Jalan Pelita IV, Sungai Penuh, Sumur Gedang, Kerinci, Jambi, Indonesia \\ 1*genisriel@gmail.com, 2mhmd_habibi@yahoo.com,33aanputra283@gmail.com \\ ${ }^{4}$ nelpitaulandari151@gmail.com
}

Artikel diterima: 30-04-2019, direvisi: 20-09-2019, diterbitkan: 30-09-2019

\begin{abstract}
Abstrak
Siswa mengalami kesulitan dalam menyelesaikan soal cerita, mengajukan pertanyaan, membuat langkah-langkah penyelesaian, serta menyelesaikan permasalahan yang diberikan. Tujuan penelitian ini adalah untuk mengetahui pengaruh model problem based learning dengan pendekatan metakognisi terhadap kemampuan pemecahan masalah matematis siswa. Jenis penelitian yang digunakan adalah penelitian eksperimen dengan menggunakan pendekatan kuantitafif. Instrumen yang digunakan adalah tes uraian. Populasi dalam penelitian ini adalah siswa kelas VIII MTs Negeri Semerah Kerinci dengan jumlah 84 orang. Pengambilan sampel dilakukan secara simple random sampling. Kelas VIII D dan VIII A masingmasing terpilih sebagai kelas eksperimen dan kelas kontrol. Analisis data kemampuan pemecahan masalah dilakukan menggunakan uji-t. Hasil penelitian menunjukkan bahwa terdapat pengaruh model pembelajaran problem based learning dengan pendekatan metakognisi terhadap kemampuan pemecahan masalah matematis siswa.

Kata Kunci: Kemampuan Pemecahan Masalah Matematis, Pendekatan Metakognisi, Problem Based Learning.

\section{The Effect of Problem Based Learning with Metacognition Approaches on Mathematical Problem Solving Skill}

Abstract

Students have difficulty in solving story problems, asking questions, taking steps to solve, and solving the problems given. The purpose of this study was to determine the effect of problembased learning models with metacognitive approaches to students' mathematical problemsolving abilities. This type of research is an experimental study using a quantitative approach. The instrument used was a description test. The population in this study was eighth-grade students of MTs Semerah Kerinci with a total of 84 people. Sampling is done by simple random sampling. Class VIII D and VIII A were respectively chosen as the experimental class and the control class. Data analysis of problem-solving ability is done using the t-test. The results showed that there was an influence of the problem-based learning model of learning with a metacognition approach to students' mathematical problem-solving abilities.

Keywords: Mathematical Problem Solving Ability, Metacognition Approach, Problem Based Learning.
\end{abstract}




\section{Pendahuluan}

Matematika bukanlah hanya sekedar kumpulan rumus-rumus dan perhitungan saja, tetapi dapat diterapkan dalam kehidupan sehari-hari untuk memecahkan berbagai masalah dan memenuhi kebutuhan praktis (Bhoke, 2017).

Suryadi dkk (Rohani, 2015) menyatakan dalam surveynya tentang "Current situation on mathematics and science education in Bandung" yang di sponsori oleh JICA, antara lain menemukan bahwa pemecahan masalah matematika merupakan salah satu kegiatan matematika yang di anggap penting baik oleh para guru maupun siswa disemua tingkatan mulai dari Sekolah Dasar sampai SMU. Akan tetapi hal tersebut masih dianggap sebagai bagian dari yang paling sulit dalam matematika baik bagi siswa dalam mempelajarinya maupun bagi guru dalam mengajarinya.

Menurut Putri, Suryani \& Jufri (2019) pemecahan masalah merupakan proses untuk mengatasi kesulitan-kesulitan yang dihadapi untuk mencapai tujuan yang diharapkan. Selanjutnya, Ahmad \& Asmaidah (2017) mengemukakan bahwa mengajarkan kemampuan pemecahan masalah kepada siswa merupakan kegiatan yang dilakukkan oleh seorang guru untuk membangkitkan siswa agar menerima dan merespon pertanyaan yang disampaikan dan membimbing siswa untuk sampai pada penyelesaian masalah.

Beberapa penelitian relevan yang telah mengkaji kemampuan pemecahan masalah matematis yang dikaitkan pada model pembelajaran lainnya, yaitu: Problem based learning dan inquiry (Nadhifah \& Afriansyah, 2016); Mastery learning (Pratiwi, Rusdi, \& Putri, 2017); Diskursus multi representasi dan reciprocal learning (Tristiyanti \& Afriansyah, 2017); Creative problem solving dan resource based learning (Sopian \& Afriansyah, 2017); Learning trajectory (Kurniawati \& Rizkianto, 2018); dan Problem centered learning dan problem based learning (Rinaldi \& Afriansyah, 2019).

$\begin{array}{ccr}\text { Pada } & \text { proses } & \text { pembelajaran } \\ \text { matematika } & \text { perlu } & \text { diutamakan }\end{array}$ kemampuan pemecahan masalah, karena dengan menghadapi masalah peserta didik akan didorong untuk berpikir secara intensif dan secara kreatif dalam menyelesaikan masalah yang dihadapinya. $\mathrm{Hal}$ ini sejalan dengan pendapat Lester (Anggo, 2011) bahwa tujuan utama mengajarkan pemecahan masalah dalam matematika adalah tidak hanya untuk melengkapi siswa dengan sekumpulan keterampilan atau proses, tetapi perlu kepada kemungkinan siswa berpikir tentang apa yang dipikirkannya. Berpikir tentang apa yang dipikirkan dalam hal ini berkaitan dengan kesadaran siswa terhadap kemampuannya untuk mengembangkan berbagai cara yang mungkin ditempuh dalam memecahkan masalah.

Berdasarkan pengamatan peneliti yang dilakukan di Madrasah Tsanawiyah Negeri (MTsN) Semerah terhadap proses pembelajaran menunjukkan siswa

Mosharafa: JumalPendidikan Matematika Volume 8, Nomor 3, September 2019 Copyright $\odot 2019$ Mosharafa: Jurnal Pendidikan Matematika 
mengalami kesulitan dalam menyelesaikan soal-soal bentuk cerita atau uraian yang diberikan. Selain itu siswa juga kesulitan dalam mengajukan pertanyaan dari masalah yang disajikan, membuat langkahlangkah sendiri dalam menyelesaikan masalah dan siswa sering menunggu guru menyampaikan rumus matematika dari pada mencarinya. Siswa hanya memikirkan hasil akhir dalam suatu permasalahan atau siswa kurang mampu dalam menyelesaikan soal dengan prosedur yang benar dan logis tanpa ada upaya atau determinasi dari siswa, (Habibi, 2018).

Sejalan dengan masalah di atas, maka perlu adanya penggunaan model pembelajaran yang dapat membantu siswa meningkatkan kemampuan pemecahan masalah dalam pembelajaran matematika. Rusman (2010) menyatakan bahwa Problem Based Learning adalah model pembelajaran yang menuntun dalam memecahkan masalah dengan lima langkah yaitu: Pertama, mengorientasi siswa pada masalah. Kedua, mengorganisasi siswa untuk belajar. Ketiga, membimbing penyelidikan individual dan kelompok. Keempat, mengembangkan dan menyajikan hasil karya. Kelima, menganalisis dan mengevaluasi proses pemecahan masalah. Selanjutnya, Silver (Aditiyas \& Saadi, 2015) mengemukakan bahwa problem based learning merupakan salah satu model pembelajaran aktif yang melibatkan siswa sebagai subyek pembelajaran yang memegang peran utama.

Mosharafa: Jurnal Pendidikan Matematika

Volume 8, Nomor 3, September 2019

Copyright @ 2019 Mosharafa: Jurnal Pendidikan Matematika
Selain itu, Komala (2017) menyatakan bahwa seorang pengajar harus bisa memilih dan melaksanakan pendekatan pemebelajaran matematika tertentu selain mereka berusaha membantu pelajat untuk mengatasi kesulitan untuk memcapai kemampuan matematik, dan mereka juga berusaha membangkitkan sikap positif terhadap matematika. Oleh karena itu, untuk memahami masalah tersebut atau memahami pengetahuan baru setiap individu juga perlu mengaitkan dan memanggil pengetahuan yang telah diketahui dengan pengetahuan baru serta membangun makna baru. Kemampuan tersebut merupakan salah satu bagian dari kemampuan metakognisi.

Menurut Flavel (Usman, 2014) metakognisi adalah suatu bentuk kemampuan untuk melihat diri pada diri sendiri sehingga apa yang dilakukan dapat terkontrol secara optimal. Selanjutnya, Desmita (2009) menyatakan bahwa Metakognisi adalah suatu proses menggugah rasa ingin tahu karena kita menggunakan proses kognitif kita untuk merenungkan proses kognitif kita sendiri. Pengetahuan ini sangat penting karena dari pengetahuan tersebut siswa dapat bekerja secara sistematis dan berhati-hati dengan adanya kontrol dari dalam diri.

Pada pelaksanaannya, aktivitas dan keterampilan tersebut dapat dicirikan oleh karakteristik metakognisi sebagaimana dikemukakan Buron dalam (Anggo, 2011) bahwa metakognisi memiliki empat karakteristik, yaitu: (1) Mengetahui tujuan yang ingin dicapai melalui proses berpikir 449 
secara sungguh-sungguh; (2) Memilih strategi untuk mencapai tujuan; (3) Mengamati proses pengembangan pengetahuan diri sendiri, untuk melihat apakah strategi yang dipilih sudah tepat; (4) Mengevaluasi hasil untuk mengetahuai apakah tujuan sudah tercapai.

Metakognisi mempunyai peran penting dalam proses pembelajaran matematika khususnya pemecahan masalah. Siswa akan sadar tentang proses berpikirnya dan mengevaluasi dirinya sendiri terhadap hasil proses berpikirnya, sehingga hal tersebut akan memperkecil kesalahan dalam menyelesaikan masalah. Berdasarkan penjelasan di atas banyak memberikan masukan dan melatarbelakangi penelitian ini, oleh karena itu peneliti tertarik ingin mengetahui bagaimana "Pengaruh Model Pembelajaran Problem Based Learning dengan pendekatan Metakognisi terhadap Kemampuan Pemecahan Masalah Matematis Siswa Kelas VIII".

Adapun tujuan dari penelitian ini adalah untuk mengetahui pengaruh pembelajaran problem based learning dengan pendekatan metakognisi terhadap kemampuan pemecahan masalah matematis siswa kelas VIII MTsN Semerah.

\section{Metode}

Penelitian ini menggunakan pendekatan kuantitatif yang diolah dengan menggunakan metode statistik. Jenis penelitian yang digunakan adalah penelitian eksperimen. Menurut Sugiyono (2009) penelitian eksperimen adalah suatu 450 penelitian yang berusaha mencari pengaruh variabel tertentu terhadap variabel yang lain dalam kondisi terkontrol secara ketat.

Populasi penelitian ini sebanyak 84 siswa. Adapun pengambilan sampel dilakukan secara simple random sampling, terpilih kelas VIII D dengan jumlah siswa 17 orang sebagai kelas eksperimen dan Kelas VIII A dengan jumlah siswa 17 orang sebagai kelas kontrol.

Dalam penelitian ini teknik pengumpuln data yang digunakan adalah teknik tes. Jenis instrumen berupa tes uraian yang berfungsi untuk melihat kemampuan siswa dalam memecahkan masalah. Tes tersebut kemudian diuji coba lapangan untuk mencari validitas dari 8 soal uji coba 5 soal kriteria valid dan 3 soal tidak memenuhi kriteria valid, uji reliabilitas diperoleh nilai harga $r_{11}=0,48$ berarti reliabilitas $0,40<r_{11} \leq 0,60$ termasuk korelasi cukup, uji indek kesukaran diperoleh 3 soal kategori mudah dan 5 soal kategori sedang, dan uji daya pembeda diperoleh 3 soal kategori sangat buruk dan 5 soal kategori cukup.

Data diperoleh melalui pemecahan masalah secara tertulis, dan dokumentasi yang diperoleh yakni mayoritas menyangkut data siswa, foto lembar jawaban tes kemampuan pemecahan masalah matematis, sarana dan prasarana, foto kegiatan proses pembelajaran dan sebagainya.

Langkah untuk menarik kesimpulan dari data tes akhir, maka dilakukan analisis data yang berupa perbandingan rata-rata Mosharafa: Jurnal Pendidikan Matematika Volume 8, Nomor 3, September 2019 Copyright $\odot 2019$ Mosharafa: Jurnal Pendidikan Matematika 
kemampuan pemecahan masalah matematis belajar siswa antara kelas eksperimen dan kelas kontrol signifikan atau tidak didasarkan dari hasil tes akhir. Langkah yang diperlukan adalah terlebih dahulu menguji normalitas dengan uji Lilliefors dan menguji homogenitas variansi dengan uji-F. Apabila keduanya terpenuhi kemudian dilanjutkan dengan menguji kesamaan dua rata-rata kelas sampel tersebut dengan uji-t.

\section{Hasil dan Pembahasan}

Data mengenai kemampuan pemecahan masalah matematis antara kelas eksperimen yang menggunakan model pembelajaran problem based learning dengan pendekatan metakognisi dengan kelas kontrol yang menggunakan model pembelajaran konvensional diperoleh hasil tes akhir yang disajikan dalam tabel berikut.

Berdasarkan tabel 1 dapat disimpulkan bahwa kemampuan pemecahan masalah matematis siswa yang menggunakan model pembelajaran problem based learning dengan pendekatan metakognisi berbeda dengan yang mengunakan model pembelajaran konvensional jika dilihat dari

Tabel 1.

Ringkasan Perbandingan Skor Kemampuan Pemecahan Masalah Matematis Kelas Eksperimen dan Kelas Kontrol

\begin{tabular}{|ccc|}
\hline Data & Eksperimen & Kontrol \\
\hline Jumlah & 1234 & 1105 \\
\hline Rata-rata & 72,58 & 65,00 \\
\hline $\begin{array}{c}\text { Simpangan } \\
\text { baku }\end{array}$ & 8,74 & 8,40 \\
\hline Varians & 76,00 & 70,62 \\
\hline
\end{tabular}

nilai varians dan rata-rata.

Berdasarkan tabel 2 dapat disimpulkan bahwa kedua kelas sampel berdistribusi normal.

Berdasarkan tabel 3 dapat disimpulkan bahwa kedua sampel memiliki variansi yang homogen.

Setelah dilakukan uji normalitas dan uji homogenitas varians kedua kelas, maka dilakukan pengujian hipotesis dengan menggunakan analisis uji-t. Pengujian ini dilakukan untuk membuktikan apakah hipotesis diterima atau tidak. Adapun hipotesis dalam penelitian ini adalah sebagai berikut:

$$
\begin{aligned}
& H_{0}: \mu_{1}<\mu_{2} \\
& H_{1}: \mu_{1}>\mu_{2}
\end{aligned}
$$

Kriteria pengujiannya adalah diterima $\mathrm{H}_{0}$ jika thitung $<t_{\text {tabel }}$ dimana $t_{\text {tabel }}$ didapat dari daftar distribusi t dengan $\mathrm{dk}=\left(n_{1}+n_{2}-\right.$ 2 ) dan peluang $\left(1-\frac{1}{2} \alpha\right)$, dalam hal lain $\mathrm{H}_{0}$ ditolak. Setelah dilakukan analisis data, diperoleh thitung sebesar 2,5776 sedangkan

Tabel 2.

Ringkasan Uji Normalitas Kelas Eksperimen dan Kelas Kontrol

\begin{tabular}{ccc}
\hline Data & Eksperimen & Kontrol \\
\hline $\begin{array}{c}\text { Jumlah } \\
\text { Siswa }\end{array}$ & 17 & 17 \\
\hline $\boldsymbol{L}_{\mathbf{0}}$ & 0,1443 & 0,1929 \\
\hline $\boldsymbol{L}_{\text {tabel }}$ & 0,206 & 0,206 \\
\hline \multicolumn{3}{c}{$\boldsymbol{\propto ⿻ \mathbf { 0 , 0 5 }}$} \\
\hline
\end{tabular}

Tabel 3 .

Ringkasan Uji Homogenitas Kelas Eksperimen dan Kelas Kontrol

\begin{tabular}{|ccc|}
\hline Data & Eksperimen & Kontrol \\
\hline Varians & 76,50 & 70,62 \\
\hline $\boldsymbol{F}_{\text {hitung }}$ & 1,0832 \\
\hline $\boldsymbol{F}_{\text {tabel }}$ & 2,33 \\
\hline \multicolumn{2}{|c|}{$\boldsymbol{F}_{\text {hitung }}<\boldsymbol{F}_{\text {tabel }}$ (homogen) } \\
\hline
\end{tabular}


nilai tabel adalah 2,0378. Hal ini berarti nilai $t_{\text {hitung }}$ lebih besar dari tabel, maka dalam hal ini berati $\mathrm{H}_{0}$ ditolak dan $\mathrm{H}_{1}$ diterima artinya terdapat perbedaan kemampuan pemecahan masalah matematis antara kelas eksperimen dengan kelas kontrol.

Berdasarkan hasil penelitian diatas dapat penulis kemukakan pembahasan sebagai berikut:

Kaitan antara kemampuan pemecahan masalah dengan model pembelajaran problem based learning dengan pendekatan metakognisi yaitu model pembelajaran problem based learning merupakan model pembelajaran yang dilakukan melalui diskusi secara berkelompok sehingga siswa dapat menyampaikan pendapat untuk memecahkan suatu permasalahan dan saling bertukar informasi.

Hal tersebut sesuai dengan yang dikemukakan oleh Wulandari \& Surjono (2013) bahwa problem based learning merupakan pemberian masalah yang berhubungan dengan kehidupan seharihari kepada setiap kelompok siswa untuk mencari alternatif solusi dari masalah tersebut. Selanjutnya, pendekatan metakognisi menyediakan cara mengendalikan pikiran yang pada akhirnya akan menghasilkan kemampuan dalam berpikir kritis yang sangat dibutuhkan dalam menyelesaikan pemecahan masalah matematika. Model pembelajaran PBLmetakognisi meliputi langkah pembelajaran sebagai berikut:

Langkah pertama yaitu pembentukan kelompok (heterogen). Pada langkah ini 452 guru membagi siswa menjadi kelompok yang beranggotakan 4-5 orang. Pada awal pembentukan kelompok, semua tujuan pembelajaran dan aturan pembentukan kelompok disampaikan kepada siswa. Aturan dalam kegiatan kelompok yaitu: (1) anggota kelompok harus saling bekerja sama dan saling mendukung; (2) setiap anggota kelompok sadar akan tanggung jawab masing-masing.

Langkah kedua, pemberian konflik (permasalahan). Pada langkah ini guru memberikan feomena (masalah) seharihari yang berkaitan dengan apa yang akan dibelajarkan kepada siswa. Pada problem based learning, pembelajaran terpusat pada masalah yang dipilih sehingga siswa tidak saja mempelajari konsep-konsep yang berhubungan dengan masalah tetapi juga metode ilmiah untuk memecahkan masalah tersebut. Hal ini sejalan dengan pernyataan Sujana (Abdurrozak, Jayadinata \& Atun, 2016) yang menyatakan bahwa problem based learning adalah suatu pembelajaran yang menyuguhkan berbagaimasalah sehingga masalah tersebut dapat dijadikan batu loncatan untuk melakukan investigasi dan penelitian. Dengan diberikannya masalah kepada siswa akan mendorong rasa ingin tahu siswa.

Langkah ketiga, mengidentifikasi masalah. Pada langkah ini, siswa memilih cara-cara terbaik untuk memecahkan masalah. Guru berperan sebagai fasilisator untuk mengarahkan tentang informasi yang diperlukan untuk memecahkan masalah, apa yang harus dilakukan, atau 
bagaimana metakognisi sehingga ia dapat mengembangkan kewaspadaan mengenai proses berpikirnya, merencanakan srategi untuk memecahkan masalah, dan memantau kesuksesan strategi tersebut.

Langkah keempat, penyelesaian masalah. Pada tahap ini, guru mendorong siswa untuk secara aktif dan mandiri mengumpulkan data dan informasi dari berbagai sumber. Guru mengajukan pertanyaan kepada siswa untuk berpikir tentang masalah dan ragam informasi yang dibutuhkan untuk sampai pada pemecahan masalah yang dapat dipertahankan. Disini siswa memilahmilah, mana informasi yang dibutuhkan dan sesuai dengan permasalahan yang ada, dan mana informasi yang tidak ia butuhkan sehingga siswa dapat menyelesaikan masalah dengan baik.

Langkah kelima, penyajian hasil. Pada langkah penyajian hasil dilakukandi depan kelas. Presentase ini, dapat disertai dengan laporan tertulis. Tentunya, penyajian hasil ini sangat dipengaruhi tingkat kemampuan pemecahan masalah siswa. Salah satu kelompok yang maju ke depan kelas untuk mempresentasikan hasilnya, sedangkan kelompok lain memperhatikan dan mengomentari hasil yang didapat oleh kelompok yang presentasi didepan kelas. Masing-masing siswa dalam kelompok, secara aktif dan bebas dalam mengutarakan pendapatnya. Peran guru disini, adalah mendorong siswa agar aktif dalam menyampaikan pendapatnya.

Mosharafa: Jumal Pendidikan Matematika

Volume 8, Nomor 3, September 2019

Copyright @ 2019 Mosharafa: Jurnal Pendidikan Matematika
Langkah keenam, evaluasi. Pada langkah ini dimaksudkan untuk membantu siswa menganalisis dan mengevaluasi proses mereka sendiri dan ketrampilan penyelidikan dan intelektual yang mereka guanakan. Selama fase ini guru, meminta siswa untuk merekonstruksi pemikiran dan aktivitas yang telah dilakukan selama proses kegiatan belajarnya.

Ditinjau dari proses pembelajaran, model pembelajaran problem based learning dengan pendekatan metakogisi dapat melibatkan siswa secara aktif dalam pembelajaran terutama pada saat mengorganisasikan siswa untuk belajar, membimbing penyelidikan secara berkelompok, menyajikan hasil karya maupun mengevaluasi hasil pemecahan masalah. Hal ini sesuai yang dinyatakan Wulandari \& Surjono (2013) bahwa problem based learnig adalah pembelajaran aktif progresif berpusat pada masalah yang tidak tertruktur sering dilakukan dengan pendekatan tim yang menekankan pada pembangunan ketrampilan yang berkaitan dengan pengambilan keputusan, diskusi dan kepemimpinan tim.

Selanjutnya, pendekatan metakognisi mengacu pada pemahaman tentang pengetahuan yang dimilikinya yang dapat mencerminkan pengunaannya secara efektif. Pada proses pembelajaran, siswa berdiskusi secara aktif dalam bertanya dan menjawab pertanyaan. Hal ini sesuai dengan penjelasan Adityas \& Saadi (2015) bahwa problem based learning merupakan model pembelajaran yang dapat 
memberikan kekuatan bagi peserta didik dalam hal memberdayakan metakognisi mereka, karena berorientasi pada proses dan menekankan siswa terlibat secara aktif dalam memecahkan permasalahan melalui kerja kelompok.

Hal tersebut terlihat saat siswa mengerjakan lembar kerja siswa, siswa yang kurang mengerti bertanya kepada temannya, sedangkan yang sudah mengerti menjelaskan kepada temannya. Saat perwakilan kelompok menyampaikan hasil kerjanya di depan kelas, masingmasing kelompok memiliki kesempatan untuk bertanya maupun memperbaiki jawaban temannya. Dalam kegiatan ini muncul interaksi antara siswa dan siswa lain serta interaksi guru dan siswa.

Pada pemecahan masalah biasanya suatu masalah (soal) memuat satu situasi yang dapat mendorong seseorang untuk menyelesaikannya akan tetapi tidak secara langsung mengetahui caranya dan juga suatu pertanyaan akan menjadi masalah jika pertanyaan itu menunjukkan adanya suatu tantangan yang tidak dapat dipecahkan dengan suatu prosedur rutin yang sudah diketahui oleh siswa.

Pada proses pembelajaran di kelas, kemampuan pemecahan masalah siswa yang mengunakan model pembelajaran problem based learning dengan pendekatan metakognisi memiliki nilai lebih tinggi dibandingkan dengan yang tidak mengunakan model pembelajaran problem based learning dengan pendekatan metakognisi. Hal ini disebabkan oleh siswa pada kelas 454 eksperimen yang menggunakan model pembelajaran problem based learning dengan pendekatan metakognisi terlibat aktif dan dapat mengontrol proses belajarnya, mulai dari tahap perencanaan, memilih strategi tepat sesuai dengan masalah yang dihadapi, kemudian mengoreksi jika ada kesalahan.

Pada proses pembelajaran di kelas yang menggunakan model konvensional, guru lebih banyak menyampaikan materi, kemudian menuliskan konsep-konsep materi yang diajarkan di papan tulis, dan siswa mencatat apa yang disampaikan guru. Selama kegiatan pembelajaran, siswa terlihat lebih pasif, guru memberikan ceramah, tanya jawab, dan tugas untuk siswa.

Hal tersebut sejalan dengan penjelasan Rasana (Juliawan, Mahadewi \& Rati,2017) yang menyatakan bahwa dalam proses pembelajaran yang menggunakan model konvensional, guru yang terlihat aktif dikelas, guru memberikan ceramah, tanya jawab dan memberikan tugas untuk siswa yang dapat mengakibatkan kemampuan pemecahan masalah matematis siswa rendah karena proses pembelajaran yang kurang bermakna. Hal tersebut sesuai dengan penjelasan Mawaddah \& Anisah (2015) bahwa kebermaknaan dalam belajar matematika ditandai dengan kesadaran apa yang dilakukan, apa yang dipahami dan apa yang tidak dipahami oleh peserta didik tentang fakta, konsep, relasi dan prosedur matematika.

Berdasarkan hasil analisis data maka dapat dilihat bahwa terdapat perbedaan Mosharafa: Jumal Pendidikan Matematika Volume 8, Nomor 3, September 2019 Copyright $\odot 2019$ Mosharafa: Jurnal Pendidikan Matematika 
yang signifikan kemampuan pemecahan masalah matematis antara kelompok siswa yang diajarkan dengan menggunakan model pembelajaran problem based learning dengan pendekatan metakognisi dan kelompok siswa yang tidak diajarkan dengan menggunakan penerapan model pembelajaran problem based learning dengan pendekatan metakognisi.

Selanjutnya, Penelitian lain yang dilaksanakan oleh Juliawan dkk (2017) mengenai pengaruh model problem based learning terhadap kemampuan pemecahan masalah matematika siswa kelas III. Penelitian tersebut menunjukkan bahwa perbedaan yang signifikan terhadap kemampuan pemecahan masalah matematika antara kelompok siswa yang diajarkan dengan model problem based learning dan kelompok siswa yang diajarkan dengan model konvensional.

Penelitian tersebut menunjukkan bahwa perbedaan yang signifikan terhadap kemampuan pemecahan masalah matematika antara kelompok siswa yang diajarkan dengan model problem based learning dan kelompok siswa yang diajarkan dengan model konvensional.

Perbedaan kemampuan pemecahan masalah matematis siswa antara kelas eksperimen dengan kelas kontrol ini membuktikan bahwa belajar matematika dengan menggunakan model pembelajaran problem based learning dengan pendekatan metakognisi dapat meningkatkan kemampuan pemecahan masalah matematis siswa. Hasil penelitian ini sejalan dengan penelitian Krisna(Lestari, Suganda \& Widiantie,2017) mengungkapkan bahwa prestasi belajar siswa dengan menggunakan model problem based learning berbantuan pertanyaan metakognisi jauh lebih baik dibandingkan dengan tanpa berbantuan pertanyaan metakognisi. Hal ini dikarenakan pada model pembelajaran problem based learning dengan pendekatan metakognisi lebih memberikan kesempatan kepada siswa untuk berpartisipasi dalam kegiatan pembelajaran.

Lebih lanjut, dalam penerapan model pembelajaran problem based learning dengan pendekatan metakognisi ini dapat menimbulkan dampak positif yang timbul saat pelaksaan kegiatan pembelajaran dikelas. Melalui penggunaan model pembelajaran problem based learning dengan pendekatan metakognisi siswa akan sadar tentang aktivitas kognitifnya sendiri atau segala sesuatu yang berhubungan dengan aktivitas kognitifnya dalam menyelesaikan masalah dan melatih siswa untuk berpikir secara mandiri.

\section{Penutup}

Dari hasil penelitian dan analisis data yang telah dilakukan maka terdapat perbedaan pada kelas eksperimen dan kelas kontrol dengan nilai rata-rata kelas eksperimen 72,58 dan kelas kontrol 65,00 maka dapat disimpulkan bahwa pembelajaran yang menggunakan model pembelajaran problem based learning 


\begin{abstract}
dengan pendekatan metakognisi berpengaruh terhadap kemampuan pemecahan masalah matematis siswa.

Berdasarkan hasil penelitian yang telah dilakukan, maka dapat dikemukakan beberapa saran, yaitu pertamabagi siswa diharapkan lebih giat belajar dan berlatih memecahkan masalah matematika. Kedua, sebagai alternatif model pembelajaran problem based learning dengan pendekatan metakognisi dapat digunakan guru dalam pembelajaran matematika untuk meningkatkan kemampuan pemecahan masalah matematis siswa. Ketiga, Diharapkan ada penelitian selanjutnya untuk mengetahui kemampuan pemecahan masalah matematis siswa pada sekolah dan materi yang berbeda.
\end{abstract}

\section{Daftar Pustaka}

Abdurrozak, R., Jayadinata, A. K., \& Atun, I. (2016). Pengaruh Model Problem Based Learning terhadap Kemampuan Berpikir Kreatif Siswa. Jurnal Pena IImiah, 1(1). 871-880.

Aditiyas, A. O., \& Saadi, P. (2015). Pengaruh Model Problem Based Learning Berbasis Aktivitas Metakognisi Terhadap Kemampuan Pemecahan Masalah Kelarutan dan Hasil Kali Kelarutan pada Siswa Kelas XI SMA. Jurnal Inovasi Pendidikan Sains, 6(2). 11-22.

Ahmad, M., \& Asmaidah, S. (2017). Pengembangan Perangkat Pembelajaran Matematika Realistik untuk Membelajarkan Kemampuan Pemecahan Masalah Matematika Siswa SMP. Mosharafa: Jurnal Pendidikan Matematika, 6(3). 373384.

Anggo, M. (2011). Pelibatan Metakognisi dalam Pemecahan Masalah Matematika. Edumatica, 1(1). 29.

Bhoke, W. (2017). Hubungan Antara Berprestasi dengan Hasil Belajar Matematika pada Siswa Kelas IV SD Gugus V Kecamatan Mauponggo. Jurnal IImiah Pendidikan, 4(1). 29-43.

Desmita. (2014). Psikologi Perkembangan Peserta Didik. Bandung: PT Remaja Rosdakarya.

Habibi, M. (2018). Self-Determination in Mathematics Learning Process by Using Generative MultiRepresentation Learning (GMRL) Model. In Journal of Physics: Conference Series (Vol. 1097, No. 1, p. 012155). IOP Publishing.

Iskandar, S. M. (2014). Pendekatan Keterampilan Metakognitif dalam Pembelajaran Sains di kelas. ERUDIO, 2(2). 14-20.

Juliawan, G. A., Mahadewi, L. P. P., \& Rati, N. W. (2017). Pengaruh Model Problem Based Learning (PBL) terhadap Kemampuan Pemecahan Masalah Matematika. Jurnal PGSD Universitas Pendidikan Ganesha, 5(2). 1-10.

Komala, E. (2017). Mathematical Resilience Mahaiswa Pada Mata Kuliah Struktur Aljabar I Menggunakan Pendekatan Explisit Intruction Mosharafa: Jurnal Pendidikan Matematika Volume 8, Nomor 3, September 2019 Copyright $\odot 2019$ Mosharafa: Jurnal Pendidikan Matematika 
Integrasi Peer Instruction. Mosharafa: Jurnal Pendidikan Matematika, 6(3). 357-364.

Kurniawati, V., \& Rizkianto, I. (2018). Pengembangan Perangkat Pembelajaran Matematika Berbasis Guided Inquiry dan Learning Trajectory Berorientasi pada Kemampuan Pemecahan Masalah. Mosharafa: Jurnal Pendidikan Matematika, 7(3). 369-380. DOI: https://doi.org/10.31980/moshar afa.v7i3.38

Kusumawati, E. \& Khair, M. S. (2015). Implementasi Model Pembelajaran Problem BasedIntructions Terhadap Kemampuan Pemecahan masalah Matematis Siswa SMA. Jurnal Pendidikan Matematika, 3(2). 213223.

Lestari, H. N., Suganda, O., \& Widiantie, R. (2017). Hubungan Antara Pengetahuan Metakognitif dengan Kemampuan Pemecahan Masalah Melalui Model Problem Based Learning pada konsep Pecemaran Lingkungan di Kelas X. Quangga: 9(2), 28-37.

Mawaddah, S., \& Anisah, H. (2015). Kemampuan Pemecahan Masalah Matematis Siswa Pada Pembelajarn Matematika dengan Menggunakan Model Pembelajaran Generatif. Jurnal Pendidikan Matematika, 3(2). 166175.

Nadhifah, G., \& Afriansyah, E. A. (2016). Peningkatan Kemampuan Pemecahan Masalah Matematis Siswa dengan

\section{Mosharafa: Jumal Pendidikan Matematika}

Volume 8, Nomor 3, September 2019

Copyright @ 2019 Mosharafa: Jurnal Pendidikan Matematika
Menerapkan Model Pembelajaran Problem Based Learning dan Inquiry. Mosharafa: Jurnal Pendidikan Matematika, 5(1). 33-44.

Pratiwi, E. A., Rusdi, A., \& Putri, A. D. (2017). Pengaruh Penggunaan Model Pembelajaran Mastery Learning (Belajar Tuntas) terhadap Kemampuan Pemecahan Masalah Matematika Siswa Kelas X SMA 'Aisyiyah 1 Palembang. Mosharafa: Jurnal Pendidikan Matematika, 6(1). 81-92.

DOI: https://doi.org/10.31980/moshar afa.v6i1.296

Putri, R. S., Suryani, M., \& Jufri, L. H. (2019). Pengaruh Penerapan Model Problem Based Learning terhadap Kemampuan Pemecahan Masalah Matematika. Mosharafa: Jurnal Pendidikan Matematika, 8(2). 331340.

Rinaldi, E., \& Afriansyah, E. A. (2019). Perbandingan Kemampuan Pemecahan Masalah Matematis Siswa antara Problem Centered Learning dan Problem Based Learning. NUMERICAL: Jurnal Matematika dan Pendidikan Matematika, 3(1). 9-18. DOI: https://doi.org/10.25217/numeri cal.v3i1.326

Rohani. (2015). Pengembangan Perangkat Pembelajaran menggunakan Pendekatan Matematika Realistik untuk Meningkatkan Kemampuan Pemecahan Masalah dan Disposisi Matematika. Edu Sciense, 2(2). 19-27. 
Sugiyono. (2009). Metode Penelitian Pendidikan Pendekatan Kuantitatif, Kualitatif, dan R\&D. Bandung: Alfabeta.

Sopian, A., \& Afriansyah, E. A. (2017). Kemampuan Proses Pemecahan Masalah Matematis Siswa melalui Model Pembelajaran Creative Problem Solving dan Resource Based Learning. Jurnal Elemen, 3(1), 97-107.

Tristiyanti, T., \& Afriansyah, E. A. (2017). Kemampuan Pemecahan Masalah Matematis Siswa Melalui Model Pembelajaran Kooperatif Tipe Diskursus Multi Representasi Dan Reciprocal Learning. JURNAL SILOGISME: Kajian IImu Matematika dan Pembelajarannya, 1(2), 4-14.

Usman. (2014). Aktivitas Metakognisi Mahasiswa Calon Guru Matematika dalam Pemecahan Masalah terbuka. Jurnal Didaktik Matematika, 1(2). 2129.

Wulandari, B., \& Surjono, H. D. (2013). Pengaruh Problem Based learning terhadap Hasil Belajar Ditinjau dari Motivasi Belajar PLC di SMK. Jurnal Pendidikan Vokasi, 3(2). 178-191.

\section{Riwayat Hidup PenUlis \\ Geni Sri Elita, S.Pd.}

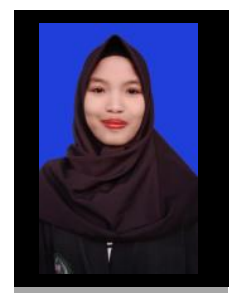

Lahir di Kerinci pada tanggal 01 Oktober 1995. Studi S1 Pendidikan matematika di Institut Agama Islam Negeri Kerinci. Lulus tahun 2019.

\section{Dr. Mhmd Habibi, M.Pd.}

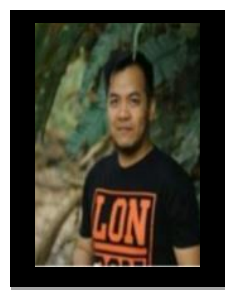

Lahir di Kerinci pada tanggal 25 Juni 1988 merupakan staf pengajar pada Program Studi Tadris Matematika IAIN Kerinci. Menyelesaikan S1 pada tahun 2010 di IAIN Kerinci, S2 diselesaikan pada tahun 2012 di Universitas Negeri Padang dan S3 diselesaikan pada tahun 2018 di Universitas Pendidikan Indonesia. Penulis juga merupakan Editor in Chief di EDUMATIKA: Jurnal Riset Pendidikan Matematika. Di samping itu penulis tercatat sebagai reviewer dan editor pada beberapa Jurnal Nasional.

\section{Aan Putra, M.Pd.}

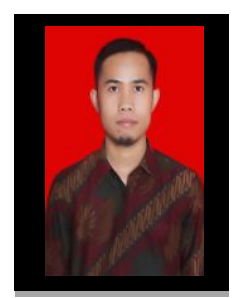

Lahir di Kerinci pada tanggal 28 Maret 1991. la merupakan staf pengajar pada Program Studi Tadris Matematika di Institut Agama Islam Negeri Kerinci Kerinci. Menyelesaikan S1 pada tahun 2013 di STKIP Muhammadiyah Sungai Penuh, S2 Pendidikan Matematika, Universitas Negeri padang, lulus tahun 2016. Penulis juga merupakan Managing Editor di EDUMATIKA: Jurnal Riset Pendidikan Matematika. Selain itu penulis tercatat sebagai penulis, editor dan reviewer pada beberapa Jurnal Nasional.

\section{Nelpita Ulandari, S.Pd.}

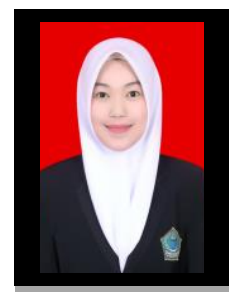

Lahir di Kerinci tanggal 15 Januari 1996. S1 Pendidikan Matematika, Institut Agama Islam Negeri Kerinci, lulus tahun 2019. Penulis pernah mempublikasikan karya ilmiah di Jurnal Cendekia: Jurnal Pendidikan Matematika. 